Reprod. Nutr. Dévelop., 1980, 20 (1 B), 301-310.

\title{
Somatomedin-A (Sm-A) bioactivity in serum and amniotic fluid as related to weight in the fetal pig
}

par J. CHARRIER

Station de Physiologie animale, I.N.R.A.,

E.N.S.A., place Viala, 34060 Montpellier Cedex, France.

Summary. Serum and amniotic fluid $\mathrm{Sm}-\mathrm{A}$ bioactivity has been assayed in the fetal pig using a double labelling technique. ${ }^{3} \mathrm{H}$-thymidine activity was always higher in fetuses and lower in sows than ${ }^{35} \mathrm{~S}$ activity. ${ }^{35} \mathrm{SO}_{4}$ uptake was not stimulated or was inhibited in about 30 p. 100 of the fetal sera. ${ }^{3} \mathrm{H}$-thymidine uptake was stimulated in all of them. There was a significant correlation $(P<0.001)$ between fetal weight and serum $\mathrm{Sm}$, as judged with both ${ }^{35} \mathrm{SO}_{4}$ and ${ }^{3} \mathrm{H}$-thymidine. No correlation was found between fetal weight and amniotic fluid $\mathrm{Sm}$, between amniotic fluid and serum $\mathrm{Sm}$ or between ${ }^{35} \mathrm{SO}_{4}$ and ${ }^{3} \mathrm{H}$ activities. It is concluded that the latter activities were due to two or more factors instead of only one.

\section{Introduction.}

Little is known about the role of hormones in the growth and differentiation of fetal tissues. Though fetal plasma contains large quantities of growth hormone, fetal growth is not appreciably perturbed by a deficiency of intrauterine growth hormone (Nanagas, 1925 ; Blizzard and Alberts, 1956 ; Rimoin, Merimee and McKusick, 1966). Similarly, normal growth has been observed in rat, rabbit, sheep and monkey fetuses after in utero decapitation or hypophysectomy (Jost, 1966 ; Liggins and Kennedy, 1968 ; Chez et al., 1970).

It is now believed that growth hormone does not act directly on skeletal growth but through the mediation of small peptidic growth factors, the somatomedins. Somatomedin-A (Sm-A) bioactivity has been defined as the factor stimulating $\mathrm{SO}_{4}$ uptake into chick embryo pelvis in vitro (Uthne, 1973). Somatomedins are found not only in blood, but in other body fluids such as the cerebrospinal fluid (Beaton, Sagel and Distiller, 1975) or amniotic fluid (Andersen, Kastrup and Lebech, 1974 ; Wright and Bala, 1975 ; Bala and Smith, 1976). Some authors studying humans have reported a significant correlation between birth size and Sm-P (Gluckman and Brinsmead, 1976), Sm-C (Underwood et al., 1978) or NSILA (Heinrich et al., 1978) in cord blood.

We wondered if these correlations could be found in animals. The pig was chosen as suitable biological material for within-litter comparisons since it produces a large number of fetuses per litter. Moreover, the individuals of a same litter have very heterogeneous weight and size, thus facilitating our study. 
Somatomedins are known to stimulate overall intracellular metabolism, at least in chondrocytes. This stimulation is usually expressed by inorganic ${ }^{35} \mathrm{SO}_{4}$ uptake into the chondroitin sulfate of the cartilageneous matrix. Also, ${ }^{3} \mathrm{H}$-thymidine uptake into DNA may act as an indicator of the stimulation of DNA synthesis and, consequently, of cell division. In the present work we used both these tracers simultaneously. As a result, it seemed that sulfation and thymidine activities were not due to one and the same factor, and thus had to be dissociated. We then attempted to establish some relationship between fetal weight and serum and/or amniotic fluid Sm-A bioactivity using both sulfation and thymidine incorporation.

\section{Material and methods.}

Serum and amniotic fluid samples. - Six 105-day pregnant sows furnished 54 fetuses. Only 4 out of the 6 maternal sera were used for assay. The uterine horns of the pregnant sows were excised immediately after slaughter. Blood was sampled, and the serum was centrifuged after clotting. The amniotic fluid free of contaminant blood was collected. That of 2 litters was discarded, reducing the number of amniotic fluids assayed from 54 to 34 . All the samples were frozen at $-25^{\circ} \mathrm{C}$ until bioassayed.

Somatomedin bioassays. - All the samples were assayed using Hall's method (1970) (incorporation of the labelled tracers into chick embryo pelvis incubated in vitro) modified by Charrier (1978) in which a post-incubation period is introduced to prevent interaction of the sample inorganic sulfate concentration. To decrease the interassay variability, all samples of the same litter were measured in the same assay.

The labelled tracers were carrier-free ${ }^{35} \mathrm{SO}_{4} \mathrm{Na}_{2}$ from the Radiochemical Centre, Amersham (England) and ${ }^{3} \mathrm{H}$-methyl thymidine from the Commissariat à l'Energie Atomique (France). The working radioactive concentration for ${ }^{35} \mathrm{SO}_{4}$ was about $1.0 \mu \mathrm{Ci} / \mathrm{ml}$ of incubation medium and that for ${ }^{3} \mathrm{H}$-thymidine $0.1 \mu \mathrm{Ci} / \mathrm{ml}$.

Calculation of results. - When possible, Sm activities were calculated from covariance analysis for a four-point parallel lines assay, according to Finney (1964). Parallel lines analysis is largely used to express a relative potency. When parallelism is not obtained, the results cannot be calculated and must be discarded as being meaningless. However, some information can be obtained from such data (as previously shown in the case of the fate of somatomedin after hypophysectomy in rabbits, Charrier and Vezinhet, 1980) when they are expressed in terms of the percentage of reference incorporation. Thus, even if the results do not have a very strict mathematical basis, they are valid since we obtained very good correlation coefficients (table 1) for Sm bioactivities from the classical parallel lines assay and the percentage of incorporation. The percentage expressed the true values well, at least for activities above $0.2 \mathrm{U} / \mathrm{ml}$ which usually show parallelism. Extrapolation of these conclusions to low values might be risky, but since no other solution was available this method seemed to be the best. When a lack of parallelism (generally due to a too-weak stimulation) in the experiments prevented the use of a parallel lines assay, the activities were expressed as a percentage of the incorporation compared to incorporation obtained with the standard at the same concentration (20 p. 100). The standard was the pooled sera of three 6-month old pigs weighing about $100-120 \mathrm{~kg}$; this pool had a conventional SmA-bioactivity of $1 \mathrm{U} / \mathrm{ml}$. The corre- 
lation coefficients, $r$, were calculated for several parameters. All the calculations for covariance analysis and the correlations were done with a programable HP 10 desk computer.

\section{TABLE 1}

Within-litfer correlation of fefal sera $S m$ bioactivity expressed in $U / m /$ and as a percentage of the standard uptake

\begin{tabular}{lcc}
\hline & ${ }^{35 S}$ & ${ }^{3} \mathrm{H}$ \\
\hline 1st litter (11) $\ldots \ldots \ldots$ & $0.96 * * *$ & $0.87 * * *$ \\
2nd litter (11) $\ldots \ldots \ldots$ & - & $0.99 * * *$ \\
3rd litter (5) $\ldots \ldots \ldots$ & $0.99 * * *$ & $0.95 * *$ \\
4th litter (7) $\ldots \ldots \ldots$ & - & $0.78 *$ \\
5th litter (9) $\ldots \ldots \ldots$ & - & $0.87 * *$ \\
6th litter (11) $\ldots \ldots \ldots$ & - & $0.88 * * *$ \\
\hline
\end{tabular}

Degrees of significance : ${ }^{*} p<0.05,{ }^{* *} p<0.01,{ }^{* * *} p<0.001$.

\section{Results.}

When possible, we calculated the correlation coefficients, $r$, of $\mathrm{Sm}$ bioactivities (in $\mathrm{U} / \mathrm{ml}$ ) and the corresponding incorporation percentage for both ${ }^{35} \mathrm{SO}_{4}$ and ${ }^{3} \mathrm{H}$ thymidine uptake. The 100 p. 100 incorporation was given by the standard at a 20 p. 100 serum concentration, and the sample incorporation was that obtained at the same concentration of the sample. The correlations for ${ }^{35} \mathrm{SO}_{4}$ uptake could only be calculated for two out of the 6 litters (table 1) ; the other litters had too many low or negative values (fig. 3).

The sera of the sows generally showed low Sm activity (fig. 1). Sulfation activity was always higher than thymidine activity.

In contrast, sulfation activity of the fetal sera was always lower than thymidine activity. A representative example in figure 2 shows the activity pattern of a single litter.

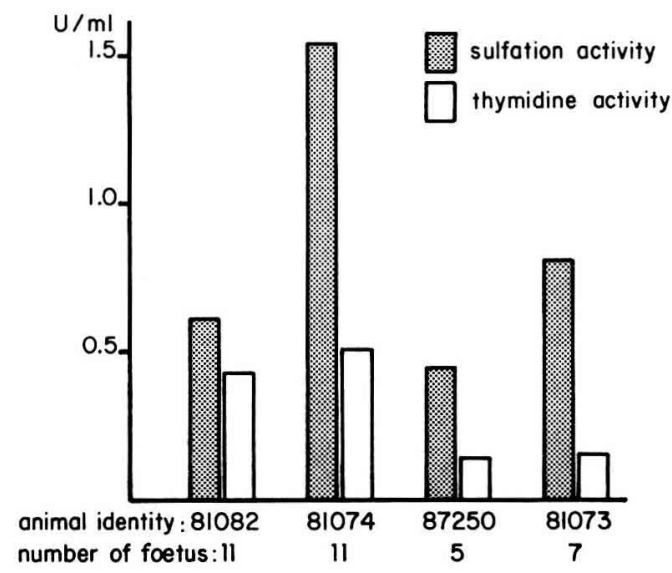

FIG. 1. - Somatomedin bioactivity in four 105-day pregnant sows. 


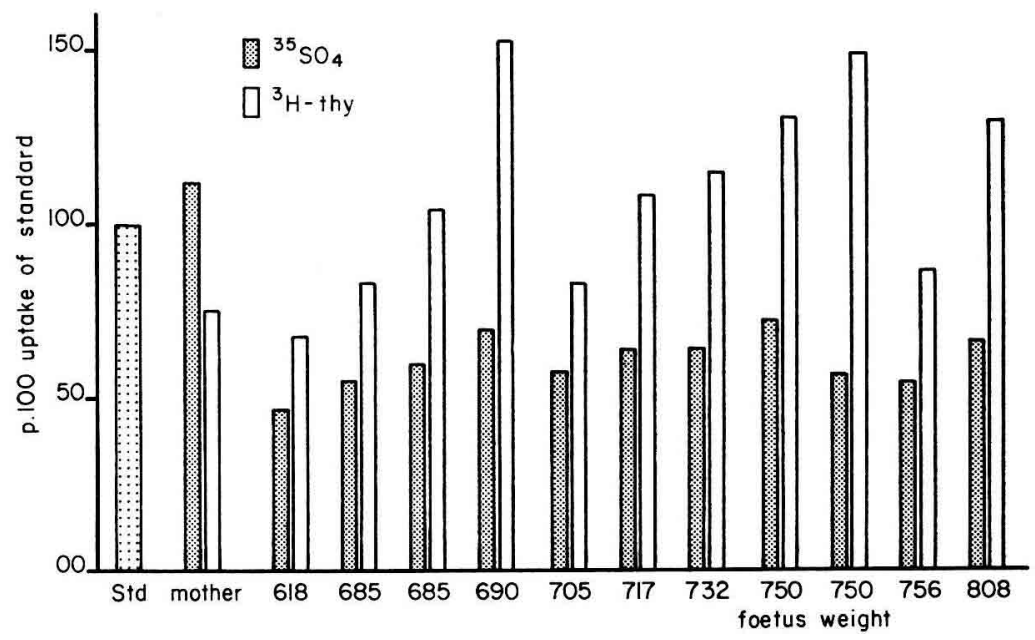

FIG. 2. - ${ }^{35} \mathrm{SO}_{4}$ or ${ }^{3} \mathrm{H}$-thy uptake obtained at 20 p. 100 serum concentration expressed as the incorporation p. 100 obtained with pig standard $(1 \mathrm{U} / \mathrm{ml})$ at the same concentration.

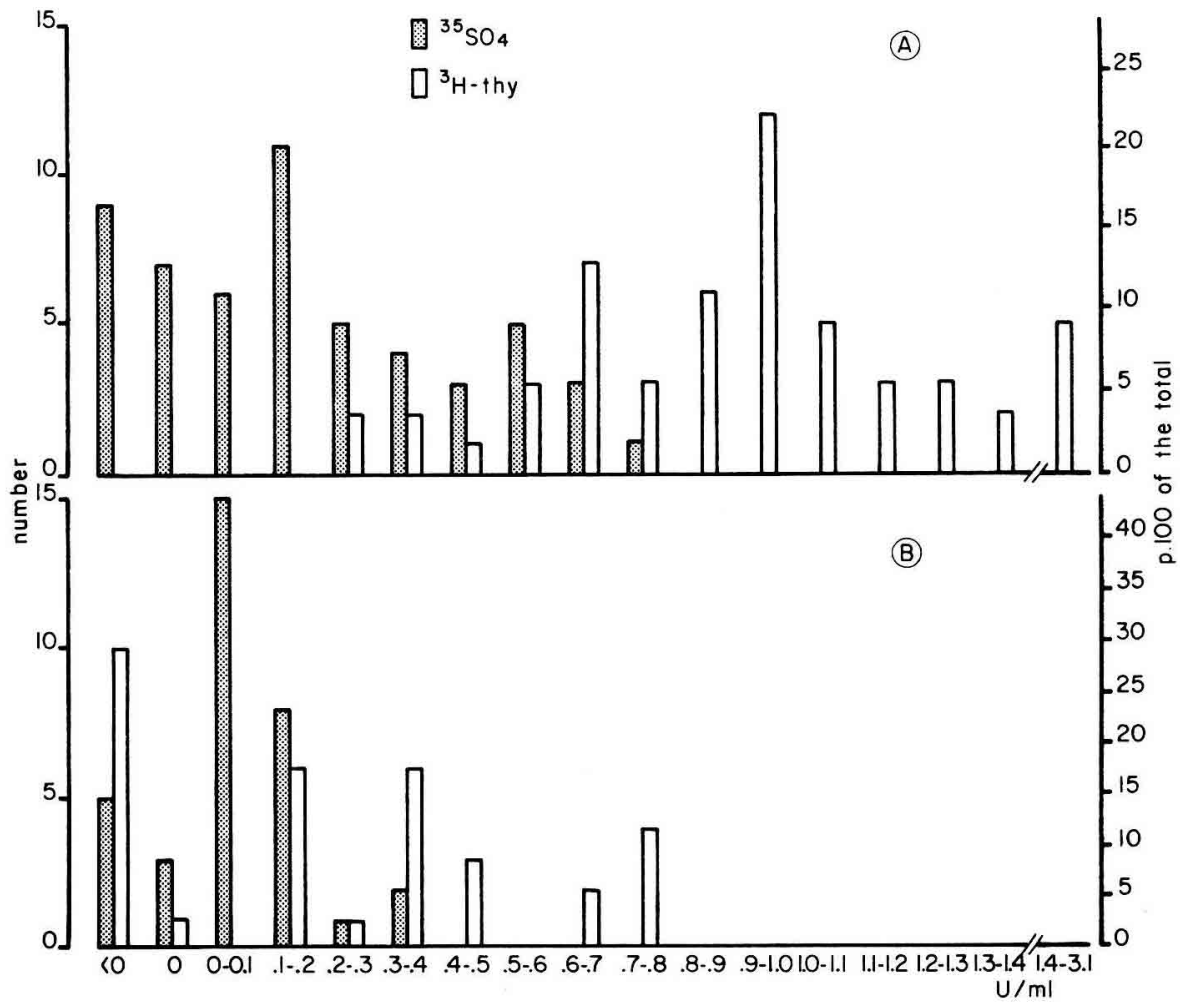

FIG. 3. - Frequency histogram for ${ }^{35} \mathrm{SO}_{4}$ and ${ }^{3} \mathrm{H}$-thy activity in serum $(A)$ or amniotic fluid $(B)$ from fetal pigs. Abscissa : $\mathrm{Sm}$ bioactivities grouped into $0.1 \mathrm{U} / \mathrm{ml}$ classes. Ordinate : number of cases in each class, or percentage of the total number. See text for activity determinations. 
All the fetal sera have low sulfation activity ; in contrast, most of them show high thymidine uptake stimulation. Figure 3 compiles all the data on the $\mathrm{Sm}$ activity of the 54 fetal sera and the 34 amniotic fluids. It has been divided in classes of $0.1 \mathrm{U} / \mathrm{ml}$ and visualized on a frequency histogram. All the samples showing incorporation under the baseline of the control pelves, incubated in buffer alone, were called negative ; they were active incorporation inhibitors. Zero activity was attributed to the samples showing incorporation at the control level. Included in the 0 to $0.1 \mathrm{U} / \mathrm{ml}$ class were samples with a response just above the control level. Between 0.1 and $0.2 \mathrm{U} / \mathrm{ml}$, one-half of the responses were parallel; the others were graphically determined. From $0.2 \mathrm{U} / \mathrm{ml}$ on, all the samples gave a parallel response.

Serum sulfation activity was confined to low levels; about one-third of the samples were zero or negative, two-thirds being below $0.2 \mathrm{U} / \mathrm{ml}$. The most stimulating one reached $0.8 \mathrm{U} / \mathrm{ml}$. In contrast, about one-third of the samples showed a thymidine activity between 0.9 to $1.1 \mathrm{U} / \mathrm{ml}$; the least active one was $0.23 \mathrm{U} / \mathrm{ml}$, and the most active $3.1 \mathrm{U} / \mathrm{ml}$. The mean values $t$ the standard error were $0.22 \pm 0.03$ and $0.95 \pm 0.06 \mathrm{U} / \mathrm{ml}$, respectively (table 2 ). However, it must be remembered that all the means were overestimated, since the negative values could not be quantified and were assessed as zero.

\section{TABLE 2}

Comparative mean values for Sm-A bioactivity (expressed in $\mathrm{U} / \mathrm{ml}$ ) in serum and amniotic fluid in 105-day gestational pigs (All negative values are considered as 0 )

\begin{tabular}{|c|c|c|c|c|}
\hline \multicolumn{3}{|c|}{ Serum } & \multicolumn{2}{|c|}{ Amniotic fluid } \\
\hline & ${ }^{35} \mathrm{~S}$ & ${ }^{3} \mathrm{H}$ & ${ }^{35} S$ & ${ }^{3} \mathrm{H}$ \\
\hline 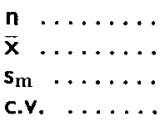 & $\begin{array}{l}54 \\
0.22 \\
0.03 \\
97 \text { p. } 100\end{array}$ & $\begin{array}{c}54 \\
0.95 \\
0.06 \\
46 \text { p. } 100\end{array}$ & $\begin{array}{c}34 \\
0.11 \\
0.02 \\
81 \text { p. } 100\end{array}$ & $\begin{array}{c}34 \\
0.27 \\
0.04 \\
96 \text { p. } 100\end{array}$ \\
\hline
\end{tabular}

$\mathrm{n}=$ number $; \overline{\mathrm{x}}==$ mean $; \mathrm{s}_{\mathrm{m}}=$ standard error ; c.v. $=$ coefficient of variation.

Amniotic fluids had a generally low activity. ${ }^{35} \mathrm{SO}_{4}$ uptake was below $0.2 \mathrm{U} / \mathrm{ml}$ in $90 \mathrm{p}$. 100 of the samples and ${ }^{3} \mathrm{H}$-thymidine uptake was also below that value in 50 p. 100 of the samples. Table 2 gives the mean values : $0.11 \pm 0.02$ and $0.27 \pm 0.04 \mathrm{U} / \mathrm{ml}$, respectively, with the same restriction as above.

Thus, there was a clear dissociation of the two types of $\mathrm{Sm}$ bioactivities, depending on whether DNA or matrix synthesis was considered. Moreover, there seemed to be no correlation between the sulfation uptake and the corresponding thymidine uptake in a sample. All litters with undetectable or negative amniotic fluid activity for both ${ }^{35} \mathrm{~S}$ and ${ }^{3} \mathrm{H}$ exhibited $\mathrm{a} r \simeq 0.9$. The single litter with measurable ${ }^{3} \mathrm{H}$ activities gave a rather poor non-significant $r$ value of 0.31 . The serum data gave similar values. Those litters showing undetectable or negative activities for ${ }^{35} \mathrm{~S}$ and very low ones for ${ }^{3} \mathrm{H}$ reached $a r \simeq 0.9$. But every time the serial numbers indicated some activity, all corre- 
lation disappeared. Therefore, we believe that those coefficients biased by depressed values were mathematical artefacts, having no true meaning, and we concluded that there was no correlation between ${ }^{35} \mathrm{~S}-\mathrm{Sm}$ and ${ }^{3} \mathrm{H}-\mathrm{Sm}$ activities.

As seen in table 3 and figure 4, there was a significant correlation between fetal weights and serum stimulating capacities for both ${ }^{35} \mathrm{~S}$ and ${ }^{3} \mathrm{H}$, but no correlation was obtained between fetal weight and amniotic fluid activities. Lastly, none could be found

TABLE 3

Overall correlations between fetal weights and serum or amniofic fluid Sm, and between fetal serum $\mathrm{Sm}$ and the corresponding amniotic $\mathrm{Sm}$. (Overall $« r$ » values include inter-lifter variability)

\begin{tabular}{|c|c|c|c|c|c|c|}
\hline \multicolumn{2}{|c|}{ Overall correlation } & \multirow{2}{*}{$\begin{array}{c}\text { Number } \\
\text { of } \\
\text { pairs }\end{array}$} & \multicolumn{4}{|c|}{ "r$»$ values } \\
\hline between & and & & ${ }^{35} \mathrm{SO}_{4}$ & $S^{+}$ & ${ }^{3} \mathrm{H}$ & $s+$ \\
\hline Fetal weight .. & Serum Sm * & 54 & 0.54 & $* * *$ & 0.46 & $* * *$ \\
\hline Fetal weight ... & Amniotic fluid $\mathrm{Sm} *$ & 34 & -0.02 & NS & -0.40 & NS \\
\hline $\begin{array}{c}\text { Fetal } \\
\mathrm{Sm}^{*} \ldots \ldots \ldots\end{array}$ & $\begin{array}{l}\text { Corresponding am- } \\
\text { niotic Sm * }\end{array}$ & 34 & 0.32 & NS & -0.05 & NS \\
\hline
\end{tabular}

* All Sm bioactivities are expressed as p. 100 of uptake with standard.

$+\mathrm{S}=$ Significance. $\left[{ }^{* * *}\right]=\mathrm{P}<0.001 ; \mathrm{NS}=$ Non-significant.

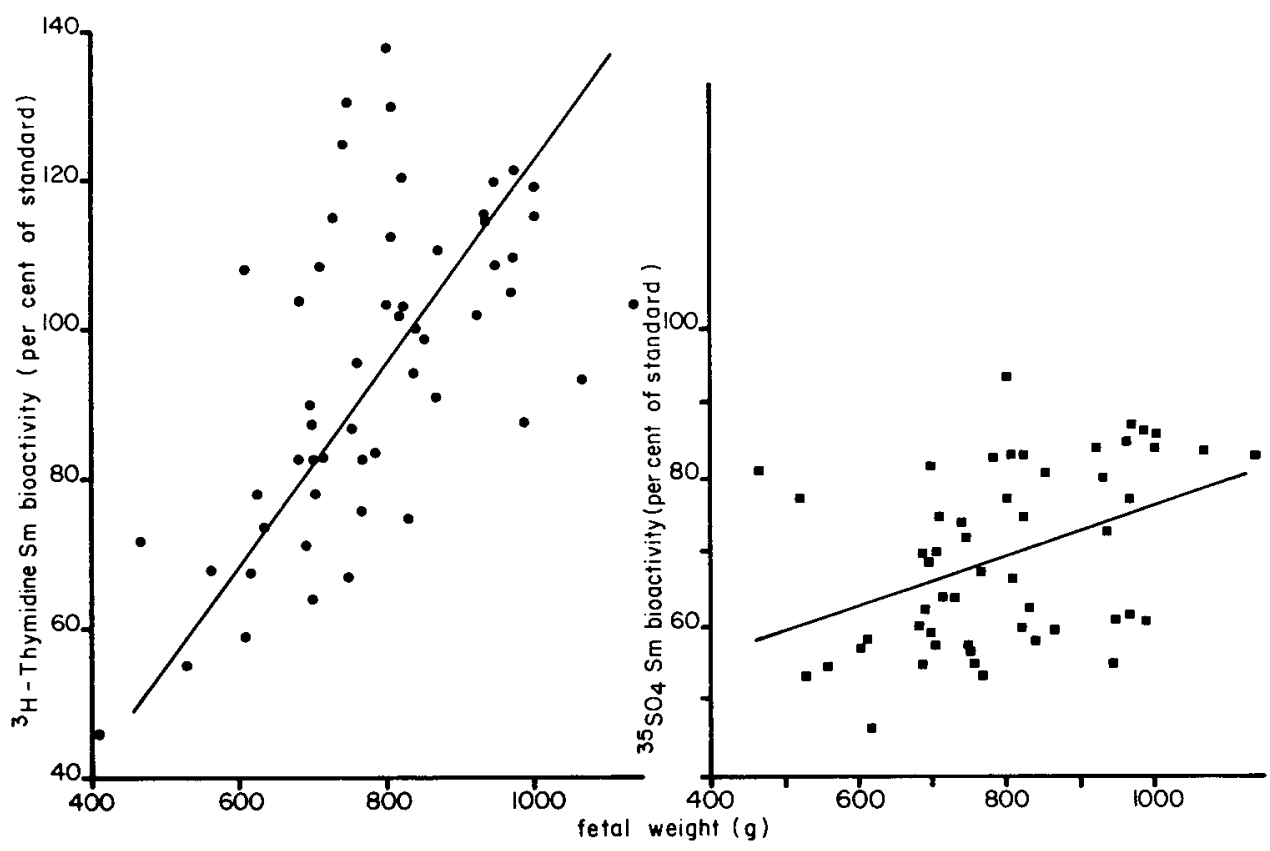

FIG. 4. - Highly significant correlation between fetal weight and ${ }^{35} \mathrm{SO}_{4}$ uptake (right, $r=0.54$ ) or ${ }^{3} \mathrm{H}$-thymidine uptake (left, $r=0.46$ ). Note difference in the slopes of the two tracers. 
between serum Sm activities and the corresponding amniotic fluids. It should be noted that the slope of the regression line between fetal weight and radioactive uptake was steeper with ${ }^{3} \mathrm{H}$-thymidine $\left(y_{\mathrm{H}}=41.1+7.2 \mathrm{x}\right)$ than with ${ }^{35} \mathrm{SO}_{1}\left(y_{\mathrm{S}}=36.1+4.2 \mathrm{x}\right)$.

\section{Discussion.}

Pregnancy in pigs lasts 115 days, and during the last month the fetus grows fast, gaining two-thirds of its birth weight (Salmon-Legagneur, 1965). In this study, we selected the 105-day stage of pregnancy falling in that period because $\mathrm{Sm}$ may affect the growth rate. Therefore, it was surprising to find that $\mathrm{Sm}\left({ }^{35} \mathrm{~S}\right.$ activity) was zero or negative at that time in 30 p. 100 of the animals, and very low in the others. Similar studies in fetal rabbit have shown that at 29 days post-coitum almost all the sera inhibit ${ }^{35} \mathrm{SO}_{4}$ incorporation (Charrier, 1979). Twenty-nine days in the rabbit and 105 days in the sow correspond approximately to 90 p. 100 of the term of pregnancy. Thus, the inhibition is more acute in rabbits than in pigs. Our mean $\left({ }^{35} \mathrm{~S}\right)$ bio-Sm-A level of $0.22 \mathrm{U} / \mathrm{ml}$ agrees with that of D'Ercole, Foushee and Underwood (1976) for Sm-C assayed by radioreceptor assay (RRA) in late gestation pig fetuses which did not change with gestational age $(0.3 \mathrm{U} / \mathrm{ml})$. In other species, and particularly in humans, a weak $\mathrm{Sm}$ activity has been consistently reported in the term fetus and the neonate : Daughaday et al. (1959), Almqvist and Rune (1961), Chesley (1962), Daughaday and Parker (1963), Kogut ef al. (1963), Giordano et al. (1976) using the rat assay; Van den Brande and Du Caju (1974), Tato et al. (1975), Hintz ef al. (1974) the pig assay; Andersen ef al. (1974), Kastrup and Andersen (1975), Pierson et al. (1976) the chick assay ; Takano et al. (1975) for Sm-A and D'Ercole et al. (1976) for Sm-C by RRA. High Sm activity $(0.91 \mathrm{U} / \mathrm{ml})$ at almost adult level has been reported only in sheep fetus during the last quarter of pregnancy by Falconer et al. (1977) using the porcine assay. All these data have been drawn from ${ }^{35} \mathrm{SO}_{4}$ uptake (or by RRA) ; but we failed to find any studies on $\mathrm{Sm}$-activity in the fetus and the neonate using ${ }^{3} \mathrm{H}$-thymidine uptake, and therefore could not compare our results to others.

Fetal weights were positively correlated with both ${ }^{35} \mathrm{~S}$ and ${ }^{3} \mathrm{H}$ serum $\mathrm{Sm}$. Similar results have been reported in humans with the porcine bioassay (Gluckman and Brinsmead, 1976) and with RRA of Sm-C (Underwood et al., 1978). A positive correlation has also been established for birth weight and NSILA (Heinrich et al., 1978). The regression slope for ${ }^{3} \mathrm{H}$-thymidine is steeper than for ${ }^{35} \mathrm{SO}_{4}$ uptake (fig. 4) because fetal body weight may be more dependent on cell multiplication than upon protein synthesis. In humans, amniotic fluid $\mathrm{Sm}$ is comparable to plasma $\mathrm{Sm}$ in the sense that the $\mathrm{Sm}$ in the former has been found to belong to two families of different molecular size, a large and a small, the small one (PM 10000) being composed of several protein groups of similar molecular size but of differing charge (Bala and Smith, 1976). If this amniotic $\mathrm{Sm}$ has a physiological role to play, it has not yet been determined. The level of Sm was very low in our pig fetuses. In humans Bala et al. (1978) using ${ }^{35} \mathrm{SO}_{4}$ uptake in the rat assay also reported a very low Sm activity in the amniotic fluid (of the same magnitude as ours in pigs) and in the plasma, but there was no correlation between them. Our sows were near term ; a similar result was reported by Chochinov et al. (1977) who observed that Sm-C increased in human amniotic fluid until 18 weeks, and then fell progressively until term. They considered the drop in the latter part of gestation to be 
due to maturation of the fetal kidney preventing transport from the fetal plasma to the amniotic fluid. If this is true in pigs, it would explain the low amniotic Sm and the lack of correlation between the sera and the corresponding amniotic fluids (table 3). However, further studies at earlier gestational stages are needed to confirm these hypotheses.

The lack of correlation between ${ }^{35} \mathrm{SO}_{4}$ and ${ }^{3} \mathrm{H}$-thymidine incorporations for a same sample, the discrepancy between them (one sample may both inhibit ${ }^{35} \mathrm{SO}_{4}$ and stimulate ${ }^{3} \mathrm{H}$-thymidine uptake), the dissociation of $\mathrm{Sm}$ activities (as judged by $\mathrm{SO}_{4}$ or by ${ }^{3} \mathrm{H}$-thymidine, fig. 3 ) and the inversion of the main types of activities occurring between adult sow and fetal sera provide much food for thought. The data suggest that these activities are not due to a single factor, as indicated by Van Wyk et al. (1972), who failed to purify the two activities into separate entities, but more likely to two or more factors.

$\mathrm{Sm}$ bioactivity is not specific and includes a lot of serum factors acting together on incorporation capacity. In addition to $\mathrm{Sm}-\mathrm{A}, \mathrm{SO}_{4}$ uplake into chick pelvis is known to depend on multiplication stimulating activity (MSA) or insulin growth factors (IGF). These factors also stimulate mitosis, as do fibroblast growth factor (FGF) and epidermal growth factor (EGF). All are closely related to the $\mathrm{Sm}$ family. The ${ }^{3} \mathrm{H}$-thymidine activity detected in fetal sera might be due to one or several of these factors rather than to $\mathrm{Sm}-\mathrm{A}$. Thus, our results would suggest a high activity in fetal life for at least one of them.

The present results suggest that in a young organism the hormonal control of growth mainly involves those peptidic growth factors concerned with mitogenesis. This would be logical since there is considerable hyperplasia at that time, whereas in adults it regresses, leaving the leading role to the factors stimulating the somatic protein synthesis. Our data could also explain why low Sm activity is systematically found in young organisms although they show a rapid growth rate : this activity has been measured in bioassays by ${ }^{35} \mathrm{SO}_{4}$ uptake, which does not seem to be a suitable tracer for this particular purpose; ${ }^{3} \mathrm{H}$-thymidine would be a better one.

5e Réunion du groupe Développement I.N.R.A. Clermont-Ferrand/Theix, 17-18 mai 1979.

Addendum : Since this paper went to press, two reports have been published supporting the hypothesis that $\mathrm{SO}_{4}$ and thymidine uptakes are not due to a single factor, thus strengthening our findings. These papers were presented at the « International symposium on growth hormone and other biologically active peptides $»$ held in Milan on 17 19 September 1979.

1) Sylvia Van Buul-Offers and Van Den Brande reported that $\mathrm{SO}_{4}$ and thymidine activities were separated into two distinct fractions after chromatography.

2) Garland, Jennings and Buchanan evidenced that the same rat serum stimulated sulfation and inhibited thymidine incorporation in the pelvic leaflet assay of Hall.

Acknowledgements. - This report was partly supported by the research grant for "Physiologie périnatale » included in the 1979-80 program of « ATP Productions animales » of the "Institut National de la Recherche Agronomique ". The author wishes to thank the "Station d'Elevage des Porcs », INRA (Jouy-en-Josas) and particularly $\operatorname{Dr}$ M. Etienne who supplied the pig samples. 
Résumé. L'activité somatomédine-A du sérum ou du liquide amniotique de fœetus de porc a été estimée par le pouvoir stimulateur de ces deux fluides sur l'incorporation in vitro de ${ }^{35} \mathrm{SO}_{4}$ dans la matrice cartilagineuse et de ${ }^{3} \mathrm{H}$-thymidine dans l'ADN de pelvis d'embryons de poulet. L'étude a porté sur 54 sérums fœtaux représentant 6 portées, sur 34 liquides amniotiques et sur le sérum de 4 mères. Le stade de prélèvement était de 105 jours de gestation. Chez les truies, l'activité « thymidine » est notablement plus faible que l'activité « sulfate ». Chez les fœtus, c'est toujours le contraire. Les activités ${ }^{35} \mathrm{~S}$ et ${ }^{3} \mathrm{H}$ du sérum de fœtus de porc sont nettement dissociées et sont respectivement de $0,22 \pm 0,03$ et $0,95 \pm 0,06 \mathrm{U} / \mathrm{ml}$ (moyenne $t$ erreur-type). Environ 30 p. 100 des sérums ont une activité nulle ou négative (inhibent l'incorporation de base des pelvis incubés dans le tampon seul) en activité ${ }^{35} \mathrm{~S}$, alors que tous stimulent l'incorporation de ${ }^{3} \mathrm{H}$-thymidine. Les liquides amniotiques présentent une faible activité $\mathrm{Sm}-\mathrm{A}$ générale. II existe une corrélation hautement significative $(\mathrm{p}<0,001)$ entre le poids du fœetus à 105 jours de gestation et la bioactivité $\mathrm{Sm}-\mathrm{A}$ du sérum exprimée à la fois par l'incorporation de ${ }^{35} \mathrm{SO}_{4}(r=0,54)$ ef de ${ }^{3} \mathrm{H}$-thymidine $(r=0,46)$. Par contre aucune corrélation n'a pu être établie entre le poids fotal et l'activité Sm du fluide amniotique, ni entre $\mathrm{Sm}$ du sérum et $\mathrm{Sm}$ du fluide amniotique correspondant, ni entre les activités ${ }^{35} \mathrm{~S}$ et ${ }^{3} \mathrm{H}$ des échantillons. Cette dernière remarque, ainsi que la dissociation des activités ${ }^{35} \mathrm{~S}$ et ${ }^{3} \mathrm{H}$ des sérums fœetaux et l'inversion des types de stimulation prépondérante entre les adultes (truies) et les fœtus, suggèrent que ces activités sont dues à des facteurs différents, et non à un seul facteur possédant à la fois les deux types d'activité stimulante. Ainsi, dans un organisme jeune, le contrôle hormonal de la croissance par les peptides facteurs de croissance serait partiellement dô aux facteurs contrôlant la mitogenèse, et leur efficacité chez l'adulte deviendrait presque négligeable. II s'ensuit que l'utilisation du traceur ${ }^{35} \mathrm{SO}_{4}$ semble mal adaptée à l'estimation des activités $\mathrm{Sm}$ du sérum des organismes jeunes. Le rôle d'autres facteurs mitogènes, tels que MSA, IGF, EGF, ou FGF, n'est pas exclu.

\section{References}

ALMQVIST S., RUNE I., 1961. Studies on sulfation factor (SF) activity of human serum. The variation of serum SF with age. Acta endocr. (Kbh), 36, 566-576.

ANDERSEN H. S., KASTRUP K. W., LEBECH P. E., 1974. The possible role of somatomedin in the growth of the human foetus. Acta pediatr. scand., 63, 328A.

BALA R. M., SMITH G. R., 1976. Partial characterization of somatomedin bioactivity in term human amniotic fluid. J. clin. Endocr. Metab., 43, 907-912.

BALA R. M., WRIGHT C., BARDAI A., SMITH G. R., 1978. Somatomedin bioactivity in serum and amniotic fluid during pregnancy. J. clin. Endocr. Metab., 46, 649-652.

BEATON G. R., SAGEL J., DISTILLER L. A., 1975. Somatomedin activity in cerebrospinal fluid. J. clin. Endocr. Metab., 40, 736-737.

BLIZZARD R. M., ALBERTS M., 1956. Hypopituitarism, hypoadrenalism and hypogonadism in the newborn infant. J. Pediatr., 48, 782-792.

CHARRIER J., 1978. Age dependent variations of somatomedin-A activity in the rabbit. Ann. Biol. anim. Bioch. Biophys., 18, 33-43.

CHARRIER J., 1979. Somatomedin-A bioactivity in serum and amniotic fluid in fetal pig and rabbit. Int. Symp. on Growth Hormone and other biologically active peptides, Milan 17-19 sept. 1979, 56 (Abstr.).

CHARRIER J., VEZINHET A., 1980. Somatomedin-A activity in rabbit serum after hypophysectomy. Reprod. Nutr. Dévelop., 20, 00-00.

CHESLEY L. C., 1962. Growth hormone activity in human pregnancy. I. Serum sulfation factor. Am. J. Obstet. Gynecol., 84, 1075-1080.

CHEZ R. A., HUTCHINSON D. A., SALAZAR H., MINTZ D., 1970. Some effects of feral and maternal hypophysectomy in pregnancy. Am. J. Obstet. Gynecol., 108, 643.

CHOCHINOV R. H., MARIZ I. K., HAJEK A., DAUGHADAY W. H., 1977. Characterization of a protein in mid-term human amniotic fluid which reacts in the somatomedin-C radioreceptor assay. J. clin. Endocr. Metab., 44, 902-908.

DAUGHADAY W. H., PARKER M. L., 1963. Sulfation factor measurement as an aid in the recognition of pituitary dwarfism. J. clin. Endocr. Metab., 23, 638. 
DAUGHADAY W. H., SALMON W. D., ALEXANDER F., 1959. Sulfation factor activity of sera from patients with pituitary disorders. J. clin. Endocr. Metab., 19, 743-758.

D'ERCOLE A. J., FOUSHEE D. B., UNDERWOOD L. E., 1976. Somatomedin-C receptor ontogeny and levels in porcine fetal and human cord serum. J. clin. Endocr. Metab., 43, 1069-1077.

FALCONER J., FORBES J. M., HART I. C., ROBINSON J. S., THORBURN G. D., 1977 . Somatomedin activity in foetal sheep following hypophysectomy or after regulation of placental size by removal of endometrial caruncles. J. Physiol. London, 272, 18-19.

FINNEY D. J., 1964. Statistical method in biological assay. $2^{\mathrm{e}}$ éd. Griffin, London, Pp. 668.

GIORDANO G., FOPPIANI E., MINUTO F., PERRONI D., 1976. Growth hormone and somatomedin behaviour in the newborn. Acta endocr. (Kbh) 81, 449-454.

GLUCKMAN P. D., BRINSMEAD M. W., 1976. Somatomedin in cord blood : relationship to gestational age and birth size. J. clin. Endocr. Metab., 43, 1378-1381.

HALL K., 1970. Quantitative determination of the sulfation activity in human serum. Acta endocr. $(K b h), 63,338-350$.

HEINRICH U. E., DRAZNIN B., JOHNSON C. J., SCHALCH D. S., 1978. NSILA (Non suppressible Insulin-like Activity) and fetal growth. Int. Symp. Somatomedins and growth. Santa Margherita Ligure, Italy, March 1-3, 1978. Abstr. 47.

HINTZ R. L., SEEDS J. M., JOHNSONBAUGH R. E., 1974. Somatomedin and growth hormone in the newborn. Pediat. Res., 8, 369 (Abstr.).

JOST A., 1966. Anterior pituitary function in foetal life, 299-323. In HARRIS G. W., DONOVAN B. T. The pifuitary gland, Vol. 2, Butterworths, London, 670 pp.

KASTRUP K. W., ANDERSEN H. J., 1975. Studies on somatomedin in newborn and its relationships to the excretion of $\mathrm{GH}$ in swine. Pediat. Res., 9, 683A.

KOGUT M. D., KAPLAN S. A., SHIMIZU C. S. N., 1963. Growth retardation : Use of sulfation factor as a bioassay for growth hormone. Pediatrics, 31, 538-551.

LIGGINS G. C., KENNEDY P. C., 1968. Effects of electrocoagulation of the foetal lamb hypophysis on growth and development. J. Endocr., 40, 371-381.

NANAGAS J. C., 1925. A comparison of the body dimensions of anencephalic human fetuses with normal fetal growth as determined by graphic analysis and empirical formulae. Am. J. Anot., 35, 455-494.

PIERSON M., GRIGNON G., MALAPRADE D., HARTEMANN P., 1976. L'activité somatomédine du sérum au cours de l'enfance chez le sujet normal et dans les retards de croissance. Ann. Biol. clin., 34, 11-18.

RIMOIN D. L., MERIMEE T. J., MCKUSICK V. A., 1966. Growth hormone deficiency in man : an isolated, recessively inherited defect. Science, 152, 1635-1636.

SALMON-LEGAGNEUR E., 1965. Cited in «Bases techniques de la production porcine ». Institut technique du porc, Paris, 1970, 151 Pp.

TAKANO K., HALL K., RITZEN M., ISELIUS C., SIEVERTSSON H., 1975. Somatomedin A in human serum, determined by radioreceptor assay. In TAKANO K., Thesis, ISBN 91-7222-133-X, Stockholm.

TATO L., Du CAJU M. V. L., PREVOT C., RAPPAPORT R., 1975. Early variations of plasma somatomedin activity in the newborn. J. clin. Endocr. Metab., 40, 534-536.

UNDERWOOD L. E., D'ERCOLE A. J., FURLANETTO R. W., HANDWERGER S., HURLEY T. W., 1978. Somatomedin and growth : a possible role for somatomedin-C in fetal growth. Int. Symp. Somatomedins and growth. Santa Margherita Ligure, Italy, March 1-3, 1978. Abstr. 50.

UTHNE K., 1973. Human somatomedins. Purification and some studies on their biological actions. Acta endocr. (Kbh.). Suppl. 175, 1-35.

VAN DEN BRANDE J. L., DU CAJU M. V. L., 1974. Plasma somatomedin activity in children with growth disturbances, 98-115. In RAITI S. Advances in Human Growth Hormone research. Symp. Baltimore, Maryland, October 9-12.

VAN WYK J. J., HALL K., VAN DEN BRANDE J. L., WEAVER R. P., UTHNE K., HINTZ R. L., HARRISON V. H., MATHEWSON P., 1972. Partial purification from human plasma of a small peptide with sulfation factor and thymidine factor activities. 155-167, in PECILE A., MULLER E. E., Growth and growth hormone, Excerpta Med., Amsterdam.

WRIGHT C., BALA R. M., 1975. Somatomedin levels in amniotic fluid, maternal and cord plasma. Clin. Res., 23, 620A. 